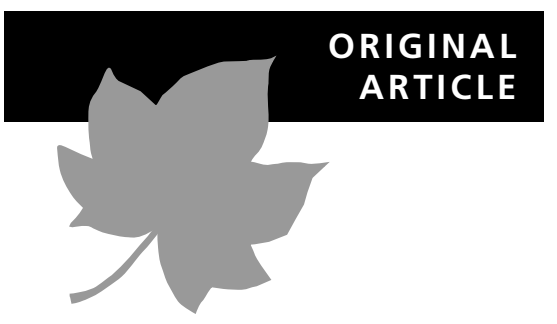

\title{
Turnover of passerine birds on islands in the Aegean Sea (Greece)
}

\author{
Johannes Foufopoulos ${ }^{1,2 \star}$ and Gregory C. Mayer ${ }^{1,3}$
}

${ }^{1}$ Department of Zoology, University of Wisconsin, Madison, WI 53706, USA,

${ }^{2}$ School of Natural Resources and Environment, University of Michigan, Ann Arbor, MI 48103, USA and

${ }^{3}$ Department of Biological Sciences, University of Wisconsin-Parkside, Kenosha, WI 53141, USA

${ }^{\star}$ Correspondence: Johannes Foufopoulos, School of Natural Resources and Environment, Dana Hall, 440 Church St., University of Michigan, Ann Arbor, MI 48109-1041, USA. E-mail: jfoufop@umich.edu

\begin{abstract}
Aim We wish to determine the effect of migratory status on turnover rates in island birds. Because turnover is influenced by factors other than migratory status, we also considered the influence of body size and physical characteristics of the islands inhabited on the probabilities of extinction and immigration.

Location The Mediterranean islands of Delos, Astypalea, Paros, Naxos and Lesvos in the Aegean Sea, Greece.

Methods The passerine birds of these islands were surveyed between 1954 and 1961 by G.E. Watson, and were resurveyed between 1988 and 1992. The effects of migratory status and body size on the probabilities of extinction and immigration were examined by $G$-tests of linear trend in proportion, and analysis of variance, respectively. A combined analysis of migratory status, body size and physical characteristics of the islands was carried out using logistic regressions of the probabilities of extinction and immigration on these factors.
\end{abstract}

Results Species number on each island changed little between surveys, with no island's species number changing by more than one species. Twelve population extinctions and 11 immigrations were recorded. The smallest island, Delos $\left(6 \mathrm{~km}^{2}\right)$, had the highest annualized relative turnover rate (1.08), while the four larger islands $\left(96-1614 \mathrm{~km}^{2}\right)$ had lower and mutually similar rates $(0.21-0.27)$. Populations on higher elevation islands were less likely to go extinct. There is no evidence for an effect of body size on the probabilities of extinction or immigration. Migratory status affected extinction and immigration probabilities differently: migratory species were more likely to immigrate, but less likely to go extinct.

Main conclusions The position of the Aegean islands along a major northsouth flyway may account for the observed effects of migratory status. The annual passage of large numbers of migrants may, via the rescue effect, decrease the chances of extinction, while at the same time increasing the chances of colonization of unoccupied islands. The likelihood of both extinction and immigration involves a complex interaction between life-history traits and island characteristics. The effects of migratory status will depend not only on consideration of vagility, vulnerability and stochasticity identified by previous authors, but also upon the location of the islands in relationship to migratory pathways.

\section{Keywords}

Aegean Sea, birds, body size, extinction, Greece, immigration, island biogeography, migratory status. 


\section{INTRODUCTION}

The numerous islands of the Aegean Sea, varying greatly in size, elevation, proximity to the mainland and geological history, present a favourable physical setting for the investigation of factors affecting faunal composition and variability; nevertheless, relatively little work addressing these questions on the islands has appeared (Wettstein, 1953; Greuter, 1971; Beutler, 1979; Trichas \& Legakis, 1987; Foufopoulos, 1997; Foufopoulos \& Ives, 1999; Dennis et al., 2000; Fattorini, 2002; Sfenthourakis et al., 2004). A notable exception is the monographic work of Watson (1964) on the distribution, ecology and systematics of the passerine birds of this region. Watson documented the distribution of passerines in the Aegean on the basis of several seasons of fieldwork from, 195461 , and considered the influence of factors such as area, habitat diversity and geological history on the composition and richness of island faunas.

In this paper, the passerine faunas as recorded by Watson are compared with the results of surveys conducted three decades later on five of the islands he studied in order to examine faunal turnover and its component phenomena, extinction and immigration (MacArthur \& Wilson, 1967). Many authors have considered what factors make a population vulnerable to extinction (Karr, 1982a,b; Pimm et al., 1988; Pimm, 1991; Sieving, 1992; Tracy \& George, 1992; Lawton, 1994; Ryan \& Siegfried, 1994; McKinney, 1997; Brashares, 2003). Population size, population size variability, body size, nesting habits and migratory status have been among such factors implicated in studies of birds. Factors promoting immigration have been less well studied. There have been many studies of invasion success (Long, 1981; Mooney \& Drake, 1986; Williamson, 1996; Shigesada \& Kawasaki, 1997; Sol et al., 2002), but to a large extent these studies have dealt with human-introduced species, and thus they considered factors affecting establishment after arrival, but not dispersal. Studies of natural immigration must consider both dispersal and establishment (Carlquist, 1965; Williams, 1969; MacArthur et al., 1972; Thornton, 1996). Among the factors that have been suggested to be positively related to immigration propensity in birds are body size (because of the ability to fly farther and faster, and to survive longer on reserves, although the larger territories needed by larger birds may impede small island colonization); longevity (because immigrants can survive until other individuals arrive); behavioural flexibility (because it aids survival in novel environments) and seasonal migration (as migrants have the opportunity to settle at previously unoccupied sites during seasonal movements).

Here, we consider how life-history characteristics of the birds influence the propensity to go extinct or to immigrate. In particular, we examine the effects of migratory status and body size. We are especially interested in the influence of migratory status, which has been proposed as a possible reason for differences in turnover rates between tropical and temperate avifaunas. Mayer \& Chipley (1992) argued that the greater number of migratory species in temperate faunas would lead to higher turnover due to the vagaries of annual recolonization; other authors considering the effect of migratory status have had somewhat different expectations (Pimm et al., 1988; Pimm, 1991; Tracy \& George, 1992). Body size is of interest because it correlates with population size (Pimm, 1991; Ebenman et al., 1995), which is the prime determinant of extinction probability (Diamond, 1984; Pimm, 1991; Lawton, 1994; Ryan \& Siegfried, 1994; Crooks et al., 2001), and thus if we wish to see the effect of migratory status we need to control for the potential effects of this additional variable.

\section{METHODS}

\section{The islands}

This study focuses on the passerine avifauna of five Aegean Islands. Three of the islands studied (Naxos, Paros and Delos) are on the main bank of the Cyclades in the south central Aegean (Fig. 1). Astypalea lies to the southeast of the Cyclades on its own bank, while the fifth island, Lesvos, lies to the northeast of the Cyclades on the continental shelf of Asia Minor. Lesvos is the third largest island in the Aegean Sea, and has the greatest habitat diversity of the islands considered in this study, including pine forest, oak savanna, macchia scrub and arid phrygana (Dafis et al., 1996). Naxos, Paros and Astypalea are mid-sized islands (Table 1) whose primary vegetation is macchia and phrygana. Delos is very small, low and dry: except for a few planted trees, arborescent vegetation is absent, and the island is covered mainly with low phrygana and bare rocks. Habitat on the islands has been influenced by human presence, mostly through clearing of the native vegetation for agriculture and animal grazing. Although over the last 40 years human settlement patterns and activities have changed in the region - notably through countryside aban-

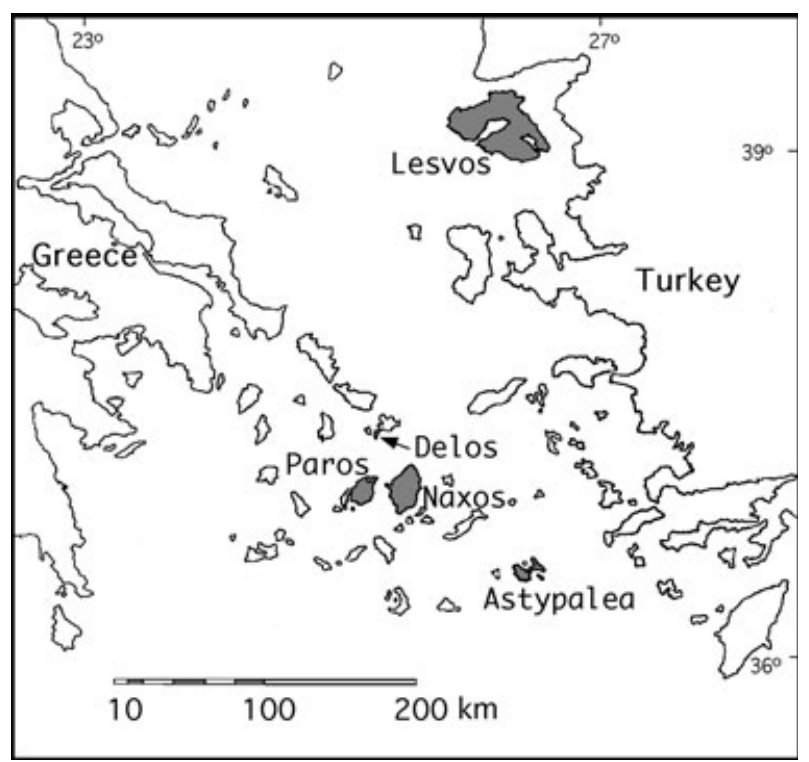

Figure 1 Map of the Aegean Sea indicating the locations of the five islands studied. 
Table 1 Characteristics and turnover rates of islands studied. Distance is the distance to the nearest source area (defined as the closest landmass with more species); Paros and Naxos are regarded as each other's source areas.

\begin{tabular}{llllll}
\hline & Delos & Astypalea & Paros & Naxos & Lesvos \\
\hline Area $\left(\mathrm{km}^{2}\right)$ & 6 & 96 & 195 & 442 & 1614 \\
Elevation $(\mathrm{m})$ & 112 & 482 & 724 & 999 & 986 \\
Distance $(\mathrm{km})$ & 2.5 & 36.5 & 5.4 & 5.4 & 7.7 \\
Early survey & 1954,1959 & 1961 & 1954,1959 & 1954,1959 & 1959,1960 \\
$\quad$ Duration $($ days $)$ & 3 & 6 & 24 & 25 & 27 \\
Late survey & 1992 & 1992 & 1992 & 1992 & 1988,1989 \\
Duration $($ days $)$ & 2 & 9 & 14 & 8 & 15,15 \\
$s_{1}$ & 7 & 15 & 20 & 24 & 58 \\
$s_{2}$ & 6 & 15 & 21 & 24 & 57 \\
$s_{\text {mean }}=\left[\left(s_{1}+s_{2}\right) / 2\right]$ & 6.5 & 15 & 20.5 & 24 & 57.5 \\
Percentage avifauna $\left(s_{1}\right):$ & $28.6 / 42.9 / 28.6$ & $6.6 / 53.3 / 40$ & $10 / 45 / 45$ & $8.3 / 45.8 / 45.8$ & $24.1 / 31.0 / 44.8$ \\
$\quad($ resident/local/migrant $)$ & & & & & \\
Extinctions $(e)$ & 3 & 1 & 1 & 2 & 5 \\
Immigrations $(i)$ & 2 & 1 & 2 & 2 & 4 \\
$\Delta t$ (years) & 35.5 & 31 & 35.5 & 35.5 & 29 \\
Turnover rate $(T)$ & 1.08 & 0.22 & 0.21 & 0.23 & 0.27 \\
Extinction rate $(E)$ & 1.21 & 0.22 & 0.14 & 0.23 & 0.30 \\
Immigration rate $(I)$ & 0.87 & 0.22 & 0.27 & 0.23 & 0.24 \\
\hline
\end{tabular}

donment and the advent of tourism (Grove \& Rackham, 2001) - these effects are mostly restricted to the coastal plains and are not likely to have had any distinct effects on the avifauna of the islands. Island areas were obtained from digitized maps (USDMA, 1986, 1991). Distance of an island to a potential source area of immigrants (defined as the closest landmass harbouring more passerine taxa than the specific island) was also obtained in a similar way. Information on maximum island elevation was acquired from published map sources (USDMA, 1986, 1991).

\section{The birds}

\section{Occurrences}

In contrast to some other studies (Haila, 1981; Haila et al., 1983) we base our analyses simply on the occurrence (presence/absence) of a species on an island rather than on actual or estimated population size.

Early reports on the birds of Naxos were made by Erhard (1858) and Krüper (1863), of Paros and Naxos by Reiser (1905), of Astypalea by Ghigi (1929), and of Astypalea, Paros, Naxos and Lesvos by Wettstein (1938). The work of Watson (1964), who spent several field seasons between 1954 and 1961 investigating the distribution of passerine birds in the Aegean, and who also evaluated and summarized the previous literature, is the most comprehensive. His records, because of the considerable effort put into amassing them, are likely to be complete or nearly so, and we have used them as the baseline for our comparisons. All of the islands in this study were visited by one of the authors (J.F.) during the breeding seasons of either 1988 (Lesvos) or 1992 (Naxos, Paros, Delos and Astypalea). During each visit all regions and distinct habitats on an island were visited by motorcycle or on foot, and inhabitants were interviewed to identify promising survey locations. Birds were identified both aurally and visually. Both we, as well as past researchers, have determined breeding status of a species on the islands indirectly, that is based on the sustained presence of singing males during the breeding season in species-appropriate habitat. In a minority of cases, further evidence for breeding came from observations of adults carrying nesting materials, feeding or leading young, or from finding the actual nests. Extensive field experience of J.F. in the region suggests that this is indeed an appropriate method to determine the presence of a species as a breeding bird on an island.

The plateauing of the species accumulation curves for the four smaller islands indicates that the surveys were complete (Fig. 2; Wilson \& Simberloff, 1969; Mayer \& Chipley, 1992; Scott, 1994). The briefest survey, two days, was of the smallest

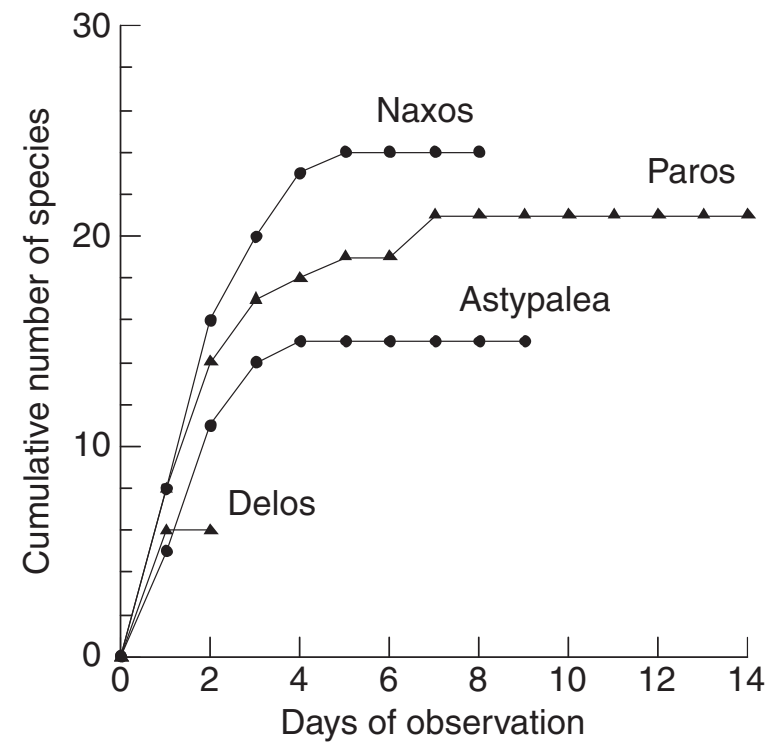

Figure 2 Species accumulation curves of passerine birds for the four islands surveyed in 1992. 
island, Delos. This very low island can be traversed in less than an hour, so that a single day of fieldwork allows an exhaustive search; no species were added on the second day.

For Lesvos, the largest island, our observations were supplemented by those of Robert A. Husband, who, in a manuscript annotated-list entitled Check list of birds. Lesbos 10th-24th May, 1989, gives the results of a visit by a group of British ornithologists in May 1989, as well as a few comments on observations made in 1987 and 1988. The combination of two independent surveys, including the fact that J.F.'s list, except for two habitat-specialist species, forms a proper subset of that of Husband's team, suggests that the survey of this island was also complete.

\section{Body size}

Body masses, in grams, were obtained from the compilation of Dunning (1993). If separate masses were given for males and females, the median of the two sex means was used. In cases in which mass data were available for more than one subspecies or location, we chose data from either the subspecies occurring in the Aegean area, or the location that was closest to our study region. For three species for which masses were unavailable (Sitta krueperi (Pelzeln), Emberiza caesia (Cretzschmar) and E. cineracea (Brehm)), we used the weight of a congener of equal total length (S. whiteheadi (Sharpe), E. schoeniclus (L.) and E. hortulana (L.), respectively; Jonsson, 1992). For a fourth such species, Sylvia ruepelli (Temminck), we used the predicted mass obtained from a regression of the logarithm of mass on total length (from Peterson et al., 1993) for eight other species of Sylvia.

\section{Migratory status}

The seasonal movements of Aegean birds vary greatly. Whereas some species, such as nuthatches and creepers, are strictly sedentary and rarely move long distances, others, such as most warblers and swallows, are long-distance migrants which breed in the Mediterranean and overwinter in sub-Saharan Africa. Previous studies of the influence of migratory status (e.g. Pimm et al., 1988; Pimm, 1991) have generally used two migratory status categories: 'migrant' and 'resident'. This categorization, however, does not reflect adequately the regional seasonal movements that many species such as finches or larks undergo. We therefore assigned species to three categories: year-round residents (called 'resident'), species with limited seasonal dispersal (called 'local'), and fully migratory species (called 'migrant') (see Appendix S1 in Supplementary Material). The species were thus arrayed on an ordinal scale of migratory tendency.

Resident status was assigned to species which show little or no movement over the course of the year. Such species are often strongly tied to specific climax habitats and will not readily cross water barriers. In the local category, we included those species which form flocks at the end of the breeding season, and, especially in winter, wander within and between islands. Typical examples of this group are serins, chaffinches, and some larks. Also included in this category are species, such as the raven, which, although territorial over most of the year, have large territories and the ability to move between islands relatively easily. Lastly, the migrant category includes those species which undergo distinct seasonal movements. Most of the species in this category migrate to suitable wintering grounds in north or central Africa, or southerly parts of the Middle East.

In assigning migratory status, standard ornithological references (Glutz von Blotzheim, 1966-97; Cramp, 1977-94; Peterson et al., 1981; Harrison, 1982; Jonsson, 1992; Handrinos \& Akriotis, 1997) and Watson (1964) were consulted. Additional information was provided by papers on bird migration through the Aegean (Wettstein, 1938; Magioris, 1987), and by unpublished reports of the Greek Ornithological Society. These sources were complemented by personal field observations over several seasons by one of the authors (J.F.).

\section{Species pool}

Simberloff (1988) has noted that in order to determine the correlates of a phenomenon (such as extinction or immigration), it is necessary to examine instances in which the phenomenon does not occur, as well as instances in which it does. For extinction, we can readily identify both those populations that persisted (i.e. in which the phenomenon did not occur) and those that perished (i.e. in which the phenomenon did occur). For immigration, although it is easy to identify those populations in which the phenomenon did occur, the non-immigrants are less readily identified. We define as the pool of potential Aegean island colonists the 63 species which occurred on any of the five islands, since all these species have demonstrated their potential for colonization of at least one Aegean island. We thus identify as failures to immigrate those populations which might have been established, but were not, and compare these to the successful immigrants.

\section{Statistical methods}

Annualized relative per cent turnover rates, $T$, were calculated as

$$
T=\left[\frac{(e+i)}{\left(s_{1}+s_{2}\right)(\Delta t)}\right] \times 100
$$

where $e$ is the number of extinctions and $i$ is the number of immigrations, $s_{1}$ and $s_{2}$ the species number during the first and second surveys, respectively, and $\Delta t$ is the survey interval. Annualized relative per cent extinction and immigration rates were calculated as

$$
E=\left[\frac{e}{\left(s_{1}\right)(\Delta t)}\right] \times 100
$$

and 


$$
I=\left[\frac{i}{\left(\left(s_{1}+s_{2}\right) / 2\right)(\Delta t)}\right] \times 100,
$$

respectively.

The effects of body size on extinction and immigration were examined by analysis of variance of the logarithmically transformed masses.

The effects of migratory status on extinction and immigration were analysed by a $G$-test for linear trend in proportion in a $2 \times k$ table. The test gives an additive partition of the total $G$ for the table into two components: one testing for the significance of a linear trend of the row proportions across the $k$ ordinal levels of the column variable, the other testing for the significance of the deviations from the linear model, that is

$$
G_{\text {total }}=G_{\text {linear }}+G_{\text {deviation }}
$$

The row proportions are the probabilities of extinction (or immigration), and there are $k=3$ ordinal levels of migratory status. $G_{\text {total }}$, which tests for deviation from a model of independence of the row and column proportions, may be calculated in the usual fashion, and has 2 d.f., or, in general, $k-1$ d.f. $G_{\text {deviation, which tests for deviation from the linear }}$ model, is computed as twice the natural logarithm of the ratio of the likelihood of the saturated model to the likelihood of the linear model, and has 1 d.f., or in general, $k-2$ d.f. $G_{\text {linear }}$ tests the significance of the linear trend against the hypothesis of independence, and has 1 d.f. A likelihood-ratio test of the significance of any $G$ value is carried out by comparing it to a $\chi^{2}$ distribution with appropriate degrees of freedom. A significant value of $G_{\text {total }}$ indicates departure from independence, a significant $G_{\text {linear }}$ indicates a significant linear trend, and a significant $G_{\text {deviation }}$ indicates departure from the linear trend. $G_{\text {linear }}$ provides a more sensitive test of the linear model than does $G_{\text {total }}$.

The probabilities of extinction and immigration may be affected not just by characteristics of the species (such as migratory status and body size), but also by the characteristics of the islands. To examine this possibility, we employed logistic regressions (Hosmer \& Lemeshow, 1989) of the probabilities of extinction and immigration. Physical characteristics of the islands (area, elevation and distance), survey interval $(\Delta t)$, and their base 10 logarithmic transformations, along with migratory status and the logarithm of body mass, were used as independent variables. The model selection strategy was to examine single variable models for significance, and then to add variables until the gain in likelihood associated with the added variable was non-significant as indicated by a likelihood-ratio test.

Because the island of Lesvos had in the first survey 58 of the 63 species in the species pool, only five species were available to immigrate to it, and thus any immigrant to Lesvos results in a substantial increment $(20 \%)$ in the overall probability of immigration to that island. This leads to Lesvos having an artificially high probability of immigration (although not necessarily a high annualized relative immigration rate). The distinctive physical characteristics of Lesvos (notably its area) would thus dominate a logistic regression analysis, not because these characteristics are necessarily important, but because of the inflated immigration probability resulting from the defined pool being little bigger than Lesvos' initial species number. Accordingly, we have excluded Lesvos from our analysis of immigration probability; for the other four islands, initial species number is substantially below the pool size.

All statistical procedures were carried out with the aid of Systat 7.0 (Wilkinson, 1997).

\section{RESULTS}

\section{Turnover rates}

A total of 63 species was recorded, 59 in each of the surveys (see Appendix S1). Twelve extinctions and 11 immigrations were recorded, so that the total number of populations present on the five islands changed from 124 to 123 . This overall near constancy is also reflected on the individual islands, on all of which species number remained the same or changed by one (Table 1). Thus, each island is apparently in species-number equilibrium.

Annualized relative percentage turnover rates are similar among islands, except for Delos (the smallest island) which had a rate about four times higher than that of the other islands (Table 1). Similar differences between Delos and all other island also exist for the two components of turnover - rates of extinction and immigration (Table 1). However, the only significant relationship between turnover rate and any physical characteristic of the islands is with the logarithm of maximum island elevation $(T=2.84-0.90(\log$ elevation $), r=0.929$, $P=0.02)$. Similarly, once the turnover rate is decomposed into separate annualized relative extinction and immigration rates, the only significant relationships are with the logarithm of elevation $(E=3.23-1.03(\log$ elevation), $r=0.919, P=0.02$; $\mathrm{I}=2.17-0.66(\log$ elevation $), r=0.935, P=0.02)$.

\section{Body mass}

The mean weight of populations going extinct $(134.0 \mathrm{~g})$ was greater than that of those which persisted $(92.7 \mathrm{~g})$, but the difference is not significant $\left(F_{[1,122]}=1.230, P=0.270\right)$. The mean weight of immigrant populations $(20.5 \mathrm{~g})$ was less than that of populations which failed to immigrate $(32.1 \mathrm{~g})$, but again the difference is not significant $\left(F_{[1,189]}=0.168\right.$, $P=0.682$ ).

\section{Migratory status}

The more migratory a population is, the lower is its probability of extinction (Table 2). A model of linear trend in proportion provides an excellent fit to the data, with almost no deviation. Thus, almost all of the departure from a hypothesis of independence may be accounted for by the inverse relationship between migratory tendency and probability of extinction. In contrast, migratory tendencies increase the probability of 
Table 2 Relationship between migratory status and extinction for 124 populations of passerine birds on islands in the Aegean Sea. Table entries are frequencies (column proportions in parentheses). $G_{\text {linear }}=4.495$ ( 1 d.f., $P=0.03$ ), $G_{\text {deviation }}=0.003$ ( 1 d.f., $P=0.96), G_{\text {total }}=4.498$ (2 d.f., $P=0.11$ ).

\begin{tabular}{|c|c|c|c|}
\hline & \multicolumn{3}{|c|}{ Migratory status } \\
\hline & Resident & Local & Migrant \\
\hline Persisted & $17(0.810)$ & $45(0.882)$ & $50(0.962)$ \\
\hline Perished & $4(0.190)$ & $6(0.118)$ & $2(0.038)$ \\
\hline
\end{tabular}

Table 3 Relationship between migratory status and immigration for 191 species-island combinations of passerine birds in the Aegean Sea. Table entries are frequencies (column proportions in parentheses). $G_{\text {linear }}=4.220$ ( 1 d.f., $\left.P=0.04\right), G_{\text {deviation }}=2.549$ (1 d.f., $P=0.11), G_{\text {total }}=6.769$ ( 2 d.f., $P=0.03$ ).

\begin{tabular}{lrrr}
\hline \multicolumn{4}{l}{ Migratory status } \\
\cline { 2 - 4 } & \multicolumn{1}{c}{ Resident } & \multicolumn{1}{c}{ Local } & \multicolumn{1}{c}{ Migrant } \\
\hline Failed-to-immigrate & $49(1.00)$ & $45(0.918)$ & $86(0.925)$ \\
Immigrated & $0(0.00)$ & $4(0.082)$ & $7(0.075)$ \\
\hline
\end{tabular}

immigration (Table 3). A linear model again provides a significant fit, but unlike for extinction, there is substantial, although still non-significant, deviation from the model. The deviation from linearity is due to both of the more migratory classes (local and migrant) having similar probabilities of immigration.

The ln-likelihoods of the models may also be considered directly in a support test (Edwards, 1992), rather than by comparing the $G$ values to the tail integral of the $\chi^{2}$ distribution as in a significance test. For such a support test, Edwards (1992) suggests a 2-unit gain in ln-likelihood (which equals a 4-unit gain in $G$ ) as a suitable criterion for the contemplation of a model containing an additional parameter. Using this criterion, we again find support for models incorporating a linear trend relating migratory status to both extinction $\left(G_{\text {linear }}=4.495\right)$ and immigration $\left(G_{\text {linear }}=4.220\right)$. Both significance and support test approaches to evaluating the hypotheses thus lead to the same result, indicating that migratory species are both more likely to immigrate and less likely to go extinct.

\section{Logistic regression}

In the logistic regression analysis of the probability of extinction, the logarithm of elevation is the single variable resulting in the greatest gain in likelihood (Table 4). Migratory status also yields a significant gain in likelihood, but body size does not, nor do any of the other island characteristics considered. Adding migratory status as a second independent variable to the model including the log of elevation results in a significant gain in likelihood. No other two-variable model gives a significant gain. Finally, no third variable, including
Table 4 Logistic regression analysis of the probability of extinction. Terms included in the models are indicated by c (constant), MIGRAT (migratory status), LOGMAS (logarithm of mass) and LOGELE (logarithm of elevation). Single variable models are tested against the constant-only model; two variable models are tested against the nested single variable model with the higher likelihood; the three variable model is tested against the nested two variable model of higher likelihood. The preferred model $\left(^{\star}\right)$ includes c, LOGELE and MIGRAT. L = ln-likelihood.

\begin{tabular}{lllll}
\hline Model & L & $G$ & d.f. & $P$ \\
\hline c & -39.424 & - & - & - \\
c, MIGRAT & -37.303 & 4.424 & 1 & 0.039 \\
c, LOGMAS & -38.891 & 1.066 & 1 & 0.302 \\
c, LOGELE & -37.088 & 4.672 & 1 & 0.020 \\
c, LOGELE, MIGRAT $\left(^{*}\right)$ & -35.155 & 3.865 & 1 & 0.049 \\
c, LOGELE, LOGMAS & -36.914 & 0.348 & 1 & 0.555 \\
c, LOGELE, MIGRAT, LOGMAS & -35.120 & 0.071 & 1 & 0.790 \\
\hline
\end{tabular}

body mass, added to the log of elevation + migratory status model significantly increases the likelihood. The best logistic model for the probability of extinction thus includes only these two variables, and is given by

$$
\begin{aligned}
& \ln \frac{p(\text { extinction })}{1-p(\text { extinction })} \\
& \quad=4.6391-0.845(\text { MIGRAT })-2.110(\text { LOGELE })
\end{aligned}
$$

where MIGRAT is migratory status and LOGELE is logarithm of elevation. The results of this analysis thus agree with those above (migratory tendencies decrease the chances of extinction, and there is no effect of body size) with the addition that island size (as represented by the log of elevation) also has a negative effect on the chance of extinction. In the logistic regression analysis of the probability of immigration, no model gave a significant fit. The logistic regression analysis thus differs in its results from the test for linear trend, in which migratory status had a significant effect on immigration probability. The logistic regression analysis differs in two ways from the test for linear trend which may account for this discrepancy: first, it posits a logistic, rather than linear, relationship; and, second, a portion of the data (that for Lesvos) has been excluded, for the reason given in the Methods. If we include Lesvos, migratory status is almost significant $(P=0.077)$, and consistent in the direction of its effect with the linear trend. However, as noted earlier, the artificially high probability of immigration to Lesvos, caused by its initial possession of nearly the whole species pool, leads to its distinctive physical characteristics dominating any analysis which includes island characteristics. Inclusion of Lesvos leads to area (this island's most distinctive physical feature) being the only variable included in a preferred logistic regression model. Thus, our data do support a positive effect of migratory tendencies on the probability of immigration, but the evidence for this is much less clear than that for the negative effect of migratory tendencies on the probability of extinction. 


\section{DISCUSSION}

\section{Species-number equilibrium and turnover}

The equilibrium theory of island biogeography (Levins \& Heatwole, 1963; MacArthur \& Wilson, 1967) proposes that the equilibrium of species number on an island is stochastic and dynamic; as such, some variation in species number is to be expected. There has been some debate as to how great the variation in species number among surveys may be while still being consistent with the idea that the number is at equilibrium (Simberloff, 1983). Although we cannot resolve this question here, for the five studied islands, in which species number changes by one or not at all over three decades, a prima facie case for equilibrium would seem to be established.

The turnover rates observed are comparable to what has been found for other north temperate islands surveyed at similar intervals (Diamond, 1969, 1984; Diamond \& May, 1977; Møller, 1980). We also find a negative relationship of turnover with island size (as represented here by log elevation).

These results are not only in line with other empirical analyses (Møller, 1980; Krauss et al., 2003; Azeria et al., 2004) but also with theoretical studies (MacArthur \& Wilson, 1967) that predict that because of the inverse relationship between population size and probability of extinction, turnover is expected to vary inversely with island size. Nevertheless, the small number of islands, and the potential for 'in-and-out' turnover (Diamond, 1971), make the annualized percentage relative turnover rates a poor measure of actual turnover (Russell et al., 1995), and lead us not to press the interpretation of these figures too far.

\section{Effects of island characteristics on extinction and immigration probabilities}

Among the island characteristics investigated here (area, elevation and distance), the only significant relationship found was between extinction probability of a population and the logarithm of elevation (Table 4), a result paralleled by the negative relationship between annualized percentage relative extinction rate (a faunistic or community measure of extinction) and the logarithm of elevation. Three mechanisms are likely to mediate this effect. First, elevation, like island area, can be viewed as an index of overall island size, and island size is positively correlated with population size, which is the most important factor determining the survival of a population on an island (Diamond, 1984; Pimm, 1991; Lawton, 1994; Ryan \& Siegfried, 1994; Crooks et al., 2001). Second, one would expect larger and higher islands to be more visible from a distance, and this 'target effect' may enhance the rescue effect (Brown \& Kodric-Brown, 1977). Finally, higher islands also provide a larger variety of vegetation zones and therefore microhabitats. Indeed, in the Aegean, higher islands support not only the typical impoverished and arid lowland scrub, but also lush high-elevation forest communities. These habitats may provide important refugia during stressful climatic events, thus buff- ering the local populations from environmental fluctuations. As a result, birds on high islands can escape adverse conditions by altitudinal migration, rather than go extinct. Diamond (1975) noted this buffering effect of habitat diversity leading to large, diverse islands being more likely to contain at least a few habitat patches that will support a species even if it has disappeared from all other suboptimal habitats.

\section{Effect of body mass on extinction and immigration probabilities}

The effect of life-history traits on the probability of extinction has been one of the central problems of conservation biology (Terborgh, 1974; McKinney, 1997; Meffe \& Carroll, 1997; Foufopoulos \& Ives, 1999; Primack, 2002). Body mass, because it is correlated in a complex manner with a multitude of other life-history traits (Calder, 1984), can effect species dispersal, establishment and persistence in a variety of direct and indirect ways (Pimm et al., 1988; Gotelli \& Graves, 1990; Tracy \& George, 1992; Gaston \& Blackburn, 1995a,b, 1996). Some of theses effects promote dispersal, establishment and persistence of larger-bodied species (e.g. stronger flying and greater longevity), while others act to retard them (e.g. smaller population sizes and lower reproductive rates). Unlike some previous studies of island birds (Pimm et al., 1988; Gotelli \& Graves, 1990; Tracy \& George, 1992; Dean \& Bond, 1994), no significant effect of body size was found in this study. This may be because body size affects species survival on an island in multiple opposing ways that make detailed analysis difficult. For example, because large bodied-birds require larger territories, they occur generally in lower densities and are therefore likely to have on average smaller island population sizes. Similarly, because larger birds tend to have lower reproductive rates, they are less likely to be able to recover quickly from population bottlenecks. On the other hand, larger-bodied birds are stronger fliers and hence better immigrants; they also tend to live longer, which allows them to ride out environmental variation more successfully (Foufopoulos \& Ives, 1999). These complex effects of body size may cancel each other out and explain why we fail to find a clear effect of body size on probabilities of extinction and immigration.

\section{Effects of migratory status on extinction and immigration probabilities}

\section{Probability of extinction}

Palearctic migration flyways require a strenuous transMediterranean crossing, immediately followed by an equally long trip over the Sahara desert. As a result, all European longdistance migrants easily fulfil two important requirements needed for successful colonization of even remote islands: (1) the physiological capacity to cross water barriers and (2) the psychological capability to commit to such a crossing (Diamond, 1981; Williams, 1981). Overwater dispersal ease 
reduces the probability of extinction in two ways. First, a sufficiently frequent influx of immigrants from a population 'source' can rescue an otherwise non-replacing island 'sink' population from extinction (Brown \& Kodric-Brown, 1977). Second, even the sporadic infusion of new genes into an island gene pool may be sufficient to head off inbreeding depression, which may otherwise result in extinction (Saccheri et al., 1998). Opposing these negative effects on extinction probability is the annual 'extinction' that migrant species undergo, requiring recolonization each year (e.g. Dale, 2001). In our study, the negative effects outweigh this opposing consideration, as both the $G$-test of linear trend and the logistic regression analysis indicated that migratory species were less likely to go extinct.

\section{Probability of immigration}

Just as their facility at dispersal may prevent extinction of a local population by providing demographic and genetic rescues, highly mobile migratory species that easily cross wide water barriers are also more likely to reach and eventually colonize an uninhabited island. In line with this, the overwhelming majority of birds occurring on the remote southern Aegean islands, as well as the oceanic island of Santorini (which was completely defaunated during a volcanic eruption in the seventeenth century BC; Grove \& Rackham, 2001), belong either to the long-distance migrant or the local disperser categories. Conversely, one would expect that evolutionary differentiation, which is promoted by the absence of gene-flow between populations, will be determined by migratory status. Indeed, all passerine species with valid Aegean endemic subspecies (Glutz von Blotzheim, 1966-97) belong to the resident category, thus supporting the notion that resident species display reduced overwater dispersal abilities. Unlike extinction probability, which may be affected in opposing ways by migratory status, it is difficult to suggest a reason why migrant species might be less likely to immigrate. In agreement with these considerations, the $G$-test of linear trend indicated that resident species are less likely to immigrate.

\section{Other studies}

Past studies have made conflicting predictions about the persistence of migratory species on islands. On the one hand, Pimm $(1984,1991)$ has argued that migrants are more likely to persist in northern climates because they escape the rigours of winter. At high latitudes, exceptionally heavy winters can indeed produce long-term changes in the distribution of nonmigratory species, e.g. Turdus pilaris L. in the Aland archipelago (Haila et al., 1983). This argument may be applicable only to regions with seasonally severe environments, such as northern Europe (but see Tworek, 2003). In contrast, Lawton (1994) has argued that migrants are more prone to extinction, as they are vulnerable to disturbances both in their breeding and their wintering grounds. Mayer \& Chipley (1992) contended that migrants would have higher turnover rates because they are both less likely to persist, and also more likely to immigrate. The vagaries of annual recolonization in migrant species should lead to some sites being unoccupied due to failure to return, while, conversely, sites unoccupied in a previous season might be readily reoccupied by returning migrants. The higher immigration probability of migrants reported here corresponds to the expectation of Mayer and Chipley.

However, in contrast to Lawton (1994) and Mayer \& Chipley (1992), we find that highly migratory species are more likely to persist on the islands examined. These results are somewhat similar to those of Haila et al. (1983) who, although, not explicitly examining turnover rates, found evidence that year-round resident species have lower incidence in a Finnish archipelago, presumably because of susceptibility to harsh winter conditions (see also Haila, 1981; Haila \& Järvinen, 1983).

Our results are also contrary to what Pimm et al. (1988) and Tracy \& George (1992) reported for small satellite islands in the British Isles, on which migratory species are more likely to go extinct than non-migrants. Several reasons may account for these differences. The British data set includes non-passerine land birds, as well as passerines. Because many extinctionrelevant life-history characteristics, such as body mass or trophic guild, vary depending on taxonomic affiliation, it is possible that sample group differences explain the diverging results.

Second, all the islands included in the British studies are smaller than $10 \mathrm{~km}^{2}$; only one of our islands (Delos) falls into that size category. Because all examined British bird populations are smaller than 20 breeding pairs, they may well behave differently from the various island populations in this study, which, occurring on islands 10-100 times larger than the British study islands, are almost certainly on average much larger.

Finally, the observed difference in the results can be attributed to the different geographic setting of the two archipelagos. All Aegean islands are located on one of the major Palearctic migration corridors. Especially during spring migration, massive numbers of land birds migrate northward using the islands as stepping stones (Magioris, 1987). Because the Aegean islands are surrounded on three sides by similar mainland habitats, and because most of the Aegean bird species have more northern distributions as well, large numbers of passerines breeding in neighbouring regions saturate the islands just prior to the breeding season. As a result, any vacant territories are likely to be occupied quickly by migrating individuals from neighbouring island or mainland populations. Migratory species populations are therefore much more likely to be either rescued or re-established in comparison to sedentary species populations.

British satellite islands are in contrast located close to the terminus of the migratory route of most bird species, and are therefore less likely to receive other north-bound migrants forced to travel across them. By virtue of their location on the 
periphery of the Palearctic, British satellite island bird populations are less likely to be rescued by migrating individuals than are their Aegean counterparts.

The analyses conducted in this study support the notion that risk of both extinction and immigration involves a complex interaction between life-history traits and island characteristics. The expectations of no previous authors have been simply met. With respect to migratory status, in particular, we note that its effects will depend not only on the considerations of vagility, vulnerability and stochasticity, identified by previous authors, but also upon the location of the islands in relationship to migratory pathways.

In conclusion, the results of two surveys separated by almost 40 years point towards little change in the numbers, but some shift in the identity of the species occurring on the islands of the Aegean Sea. A limited number of population extinctions were compensated by almost the same number of population establishments. Although we were not able to detect any effects of body size on the probabilities of immigration or extinction, we found that migratory status was related to both of these variables, albeit in opposite directions. Specifically, whereas migratory species tended to have higher colonization rates, they also tended to have lower extinction rates. This pattern is best explained by the high vagility of these taxa, which on the one hand allows them to rescue populations that may be in trouble, and on the other hand to reach and colonize more easily islands that have available habitat.

\section{ACKNOWLEDGEMENTS}

We are grateful to A. Ives for discussion, R. Bleiweiss for essential resources, to both of them for comments on the manuscript, and to L. Wilkinson and D. Nichols for statistical advice. We are also very thankful to R. A. Husband for granting us access to data collected, and to the Greek Ornithological Society for making records available to us. This work was supported by a Vilas Fellowship from the Graduate School, University of Wisconsin, Madison, and the Guyer Fund of the Department of Zoology, University of Wisconsin, Madison.

\section{REFERENCES}

Azeria, E.T., Carlson, A., Part, T. \& Wiklund, C.G. (2004) Temporal dynamics and nestedness of an oceanic island bird fauna. Acta Universitatis Agriculturae Sueciae Silvestria, 311, $1-22$.

Beutler, A. (1979) General principles in the distribution of reptiles and amphibians in the Aegean. Biologia Gallo-Hellenica, 8, 337-344.

Brashares, J.S. (2003) Ecological, behavioral, and life-history correlates of mammal extinctions in West Africa. Conservation Biology, 17, 733-743.

Brown, J.H. \& Kodric-Brown, A. (1977) Turnover rates in insular biogeography: effect of immigration on extinction. Ecology, 58, 445-449.
Calder, W.A. (1984) Size, function, and life history. Harvard University Press, Cambridge, MA.

Carlquist, S. (1965) Island life. Natural History Press, Garden City, NY.

Cramp, S. (ed.) (1977-94) Handbook of the birds of Europe, the Middle East and North Africa: the birds of the western Palaearctic, 9 vols. Oxford University Press, Oxford.

Crooks, K.R., Suarez, A.V., Bolger, D.T. \& Soule, M.E. (2001) Extinction and colonization of birds on habitat islands. Conservation Biology, 15, 159-172.

Dafis, S., Papastergiadou, E., Georghiou, K., Babalonas, D., Georgiadis, T., Papageorgiou, M., Lazaridou, T. \& Tsiaoussi, V. (1996) The Greek Habitat Project Natura 2000: an overview. Goulandris Natural History Museum, Athens.

Dale, S. (2001) Female-biased dispersal, low female recruitment, unpaired males, and the extinction of small and isolated bird populations. Oikos, 92, 344-356.

Dean, W.R.J. \& Bond, W.J. (1994) Apparent avian extinctions from islands in a man-made lake, South Africa. Ostrich, 65, $7-13$.

Dennis, R.L.H., Shreeve, T.G., Olivier, A. \& Coutsis, J.G. (2000) Contemporary geography dominates butterfly diversity gradients within the Aegean archipelago (Lepidoptera: Papilionoidea, Hesperioidea). Journal of Biogeography, 27, 1365-1383.

Diamond, J.M. (1969) Avifaunal equilibria and species turnover rates on the Channel Islands of California. Proceedings of the National Academy of Sciences USA, 64, 57-63.

Diamond, J.M. (1971) Comparison of faunal equilibrium turnover rates on a tropical island and a temperate island. Proceedings of the National Academy of Sciences USA, 68, 2742-2745.

Diamond, J.M. (1975) Assembly of species communities. Ecology and evolution of communities (ed by M.L. Cody and J.M. Diamond), pp. 342-444. Harvard University Press, Cambridge, MA.

Diamond, J.M. (1981) Flightlessness and fear of flying in island species. Nature, 293, 507-508.

Diamond, J.M. (1984) Historic extinctions: a Rosetta stone for understanding prehistoric extinctions. Quaternary extinctions: a prehistoric revolution (ed. by P.S. Martin and R.G. Klein), pp. 824-862. University of Arizona Press, Tucson, AZ.

Diamond, J.M. \& May, R.M. (1977) Species turnover rates on islands: dependence on census interval. Science, 197, 266-270.

Dunning, J.B. (1993) Handbook of avian masses. CRC Press, Boca Raton, FL.

Ebenman, B., Hedenstrom, A., Wennergren, U., Ekstam, B., Landin, J. \& Tyrberg, T. (1995) The relationship between population density and body size: the role of extinction and mobility. Oikos, 73, 225-230.

Edwards, A.W.F. (1992) Likelihood, 2nd edn. Johns Hopkins University Press, Baltimore, MD.

Erhard (1858) Katalog der auf den Cycladen einheimischen und überwinternden oder nur durchziehenden Arten von Vögeln. Naumannia, 8, 1-26. 
Fattorini, S. (2002) Biogeography of tenebrionid beetles (Coleoptera, Tenebrionidae) on the Aegean Islands (Greece). Journal of Biogeography, 29, 49-67.

Foufopoulos, J. (1997) The reptile fauna of the Northern Dodecanese (Aegean Islands, Greece). Herpetozoa 10, 3-12.

Foufopoulos, J. \& Ives, A.R. (1999) Reptile extinctions on land-bridge islands: life history attributes and vulnerability to extinction. The American Naturalist 153, 1-25.

Gaston, K.J. \& Blackburn, T.M. (1995a) Birds, body size, and the threat of extinction. Philosophical Transactions of the Royal Society of London Series B, Biological Sciences, 347, 205-212.

Gaston, K.J. \& Blackburn, T.M. (1995b) Rarity and body size: some cautionary remarks. Conservation Biology, 9, 210-213.

Gaston, K.J. \& Blackburn, T.M. (1996) Conservation implications of geographic range size-body size relationships. Conservation Biology, 10, 638-646.

Ghigi, A. (1929) Ricerche faunistiche nelle isole Italiane dell'Egeo. Uccelli. Archivo Zoologico Italiano, 13, 25-30.

Glutz von Blotzheim, U.N. (ed.) (1966-97) Handbuch der Vögel Mitteleuropas, 14 vols. Aula Verlag, Wiesbaden.

Gotelli, N.J. \& Graves, G.R. (1990) Body size and the occurrence of avian species on land-bridge islands. Journal of Biogeography, 17, 315-325.

Greuter, W. (1971) Betrachtungen zur Pflanzengeographie der Südägäis. Evolution in the Aegean (ed. by A. Strid), pp. 4964. Opera Botanica 30, C.W.K. Gleerup, Lund, Sweden.

Grove, A.T. \& Rackham, O. (2001) The nature of mediterranean Europe: an ecological history. Yale University Press, New Haven, CT.

Haila, Y. (1981) Winter bird communities in the Aland archipelago: an island biogeographic point of view. Holarctic Ecology, 4, 174-183.

Haila, Y. \& Järvinen, O. (1983) Land bird communities on a Finnish island: species impoverishment and abundance patterns. Oikos, 41, 255-273.

Haila, Y., Järvinen, O. \& Kuusela, S. (1983) Colonization of islands by land birds: prevalence functions in a Finnish archipelago. Journal of Biogeography, 10, 499-531.

Handrinos, G. \& Akriotis, T. (1997) The birds of Greece. Chrisopher Helm, London.

Harrison, C. (1982) An atlas of the birds of the western Palaearctic. Princeton University Press, Princeton, NJ.

Hosmer, D.W. \& Lemeshow, S. (1989) Applied logistic regression. Wiley, New York.

Jonsson, L. (1992) Die Vögel Europas und des Mittelmeerraumes. Franck-Kosmos, Stuttgart.

Karr, J.R. (1982a) Avian extinction on Barro Colorado Island, Panama: a reassessment. The American Naturalist, 119, 220-239.

Karr, J.R. (1982b) Population variability and extinction in the avifauna of a tropical landbridge island. Ecology, 63, 19751978.

Krauss, J., Steffan-Dewenter, I. \& Tscjarntke, T. (2003) Local species immigration, extinction, and turnover of butterflies in relation to habitat area and habitat isolation. Oecologia, 137, 591-602.

Krüper, T. (1863) Die Brutvögel von Naxos. Journal für Ornithologie, 11, 402-407.

Lawton, J.H. (1994) Population dynamic principles. Philosophical Transactions of the Royal Society of London Series B, Biological Sciences, 344, 61-68.

Levins, R. \& Heatwole, H. (1963) On the distribution of organisms on islands. Caribbean Journal of Science, 3, $173-177$.

Long, J.L. (1981) Introduced birds of the world. David and Charles, Newton Abbot, UK.

Møller, A.P. (1980) Ynglefugleændring, -indvandring og -uddøen på nogle danske øer. Dansk Ornithologisk Forenings Tidsskrift, 74, 123-126.

MacArthur, R.H. \& Wilson, E.O. (1967) The theory of island biogeography. Princeton University Press, Princeton, NJ.

MacArthur, R.H., Diamond, J.M. \& Karr, J.R. (1972) Density compensation in island faunas. Ecology, 53, 330-342.

Magioris, S.N. (1987) Migration over the Cyclades, central Aegean. Ringing and Migration, 8, 109-114.

Mayer, G.C. \& Chipley, R.M. (1992) Turnover in the avifauna of Guana Island, British Virgin Islands. Journal of Animal Ecology, 61, 561-566.

McKinney, M.L. (1997) Extinction vulnerability and selectivity: combining ecological and paleontological views. Annual Review of Ecology and Systematics, 28, 495-516.

Meffe, G.K. \& Carroll, C.R. (1997) Principles of conservation biology, 2nd edn. Sinauer, Sunderland, MA.

Mooney, H.A. \& Drake, J.A. (1986) Ecology of biological invasions of North America and Hawaii. Springer-Verlag, New York.

Peterson, R.T., Mountfort, G., Hollom, P.A.D., Kannellis, A. \&

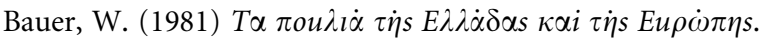
Chrysos Typos, Athens. English title: The birds of Greece and Europe.

Peterson, R.T., Mountfort, G. \& Hollom, P.A.D. (1993) A field guide to the birds of Britain and Europe. Houghton Mifflin, Boston.

Pimm, S.L. (1984) Food chains and return times. Ecological communities: conceptual issues and the evidence (ed. by D.R. Strong, D. Simberloff, L.G. Abele and A.B. Thistle), pp. 397412. Princeton University Press, Princeton, NJ.

Pimm, S.L. (1991) The balance of nature? University of Chicago Press, Chicago, IL.

Pimm, S.L., Jones, H.L. \& Diamond, J. (1988) On the risk of extinction. The American Naturalist, 132, 757-785.

Primack, R.B. (2002) Essentials of conservation biology, 3rd edn. Sinauer, Sunderland, MA.

Reiser, O. (1905) Materialien zu einer Ornis Balcanica III. Griechenland und die Griechischen Inseln (mit Ausnahme von Kreta). Gerold, Vienna.

Russell, G.J., Diamond, J.M., Pimm, S.L. \& Reed, T.M. (1995) A century of turnover: community dynamics at three timescales. Journal of Animal Ecology, 64, 628-641. 
Ryan, P.G. \& Siegfried, W.R. (1994) The variability of small populations of birds: an empirical investigation of vulnerability. Minimum animal populations (ed. by H. Remmert), pp. 3-22. Springer-Verlag, Berlin.

Saccheri, I., Kuussaari, M., Kankare, M., Vikman, P., Fortelius, W. \& Hanski, I. (1998) Inbreeding and extinction in a butterfly metapopulation. Nature, 392, 491-494.

Scott, N.J. (1994) Complete species inventories. Measuring and monitoring biological diversity. Standard methods for amphibians (ed. by W.R. Heyer, M.A. Donnelly, R.W. McDiarmid, L.C. Hayek and M.S. Foster), pp. 78-84. Smithsonian Institution Press, Washington, DC.

Sfenthourakis, S., Giokas, S. \& Tzanatos, E. (2004) From sampling stations to archipelagos: investigating aspects of the assemblage of insular biota. Global Ecology and Biogeography, 13, 23-35.

Shigesada, N. \& Kawasaki, K. (1997) Biological invasions: theory and practice. Oxford University Press, Oxford.

Sieving, K.E. (1992) Nest predation and differential insular extinction among selected forest birds of central Panama. Ecology, 73, 2310-2328.

Simberloff, D. (1983) When is an island community in equilibrium? Science, 220, 1275-1277.

Simberloff, D. (1988) Is this trip necessary? Condor, 90, 739-740. Sol, D., Timmermans, S. \& Lefebvre, L. (2002) Behavioural flexibility and invasion success in birds. Animal Behaviour, 63, 495-502.

Terborgh, J. (1974) Preservation of natural diversity: the problem of extinction prone species. Bioscience, 24, 715-722.

Thornton, I. (1996) Krakatau. Harvard University Press, Cambridge, MA.

Tracy, R.C. \& George, L.T. (1992) On the determinants of extinction. The American Naturalist, 139, 102-122.

Trichas, A. \& Legakis, A. (1987) General considerations on the distribution of Coleoptera in the Aegean Islands. Biologia Gallo-Hellenica, 13, 127-132.

Tworek, S. (2003) Local extinction, colonization and turnover rates of breeding birds in fragmented landscapes: differences between migratory guilds. Ornis Fennica, 80, 49-62.

USDMA (US Defense Mapping Agency) (1986) Mediterranean Sea, Greece-Turkey, Aegean Sea. US Defense Mapping Agency, Washington, DC.

USDMA (US Defense Mapping Agency) (1991) Mediterranean, Aegean Sea, Greece-south coast, Kikladhes Nisoi to Kriti. US Defense Mapping Agency, Washington, DC.

Watson, G.E. (1964) Ecology and evolution of passerine birds on the islands of the Aegean Sea. $\mathrm{PhD}$ thesis, Yale University.

Wettstein, O.V. (1938) Die Vogelwelt der Ägäis. Journal für Ornithologie, 86, 9-53.

Wettstein, O.V. (1953) Herpetologia Aegea. Sitzungsberichte der Österreichischen Akademie der Wissenschaften, Wien, 162, 651-833.
Wilkinson, L. (1997) SYSTAT 7.0. SPSS Inc., Chicago, IL. Williams, E.E. (1969) The ecology of colonization as seen in the zoogeography of anoline lizards on small islands. Quarterly Review of Biology, 44, 345-389.

Williams, G.R. (1981) Aspects of avian biogeography in New Zealand. Journal of Biogeography, 8, 439-456.

Williamson, M. (1996) Biological invasions. Chapman \& Hall, London.

Wilson, E.O. \& Simberloff, D.S. (1969) Experimental zoogeography of islands: defaunation and monitoring techniques. Ecology, 50, 267-278.

\section{BIOSKETCHES}

Johannes Foufopoulos is an Assistant Professor at the School of Natural Resources and Environment at the University of Michigan, Ann Arbor. An Aegean native, he is interested in the ecological and evolutionary processes operating in small island populations. He has conducted research on island vertebrates in several island groups including Melanesia, Hawaii and the Galapagos.

Gregory C. Mayer is an Associate Professor of Biological Sciences at the University of Wisconsin-Parkside, Kenosha. Born and raised on Long Island, New York, he has long been interested in island biogeography. His research interests focus on the ecology, evolution and biogeography of insular vertebrates, with especial reference to West Indian amphibians and reptiles, and the application of likelihood inference to ecological hypotheses.

Editor: José María Fernández-Palacios

\section{SUPPLEMENTARY MATERIAL}

The following supplementary material is available for this article online

Appendix S1 Occurrence of 63 species of birds on five islands in the Aegean Sea.

This material is available as part of the online article from: http:// www.blackwell-synergy.com/doi/abs/10.1111/j.1365-2699. 2007.01695.x

Please note: Blackwell Publishing are not responsible for the content or functionality of any supplementary materials supplied by the authors. Any queries (other than missing material) should be directed to the corresponding author for the article. 